\title{
GIS multi-criteria decision analysis for assessment and mapping of neotectonic landscape deformation: A case study from Crete.
}

\section{Athanasios V. Argyriou ${ }^{\text {a,b }}{ }^{*}$, Richard M. Teeuw ${ }^{a}$, Derek Rust ${ }^{a}$, Apostolos Sarris ${ }^{b}$}

${ }^{a}$ School of Earth and Environmental Sciences, University of Portsmouth, Portsmouth PO1 3QL, UK.

${ }^{\mathrm{b}}$ Laboratory of Geophysical - Satellite Remote Sensing \& Archaeo-environment, Institute for Mediterranean Studies (I.M.S.) / Foundation of Research \& Technology (F.O.R.T.H.), Melissinou \& Nikiforou Foka 130, Rethymno 74100, Greece.

* Corresponding author: A.V. Argyriou, telephone: +302831056627 , fax: +302831025810 , argyriou.nasos@gmail.com.

\begin{abstract}
This study of drainage systems in a tectonically active region is based on the Geographical Information Systems (GIS) integration of data from an analytic hierarchy process (AHP) and a weighted linear combination (WLC) procedure with multiple criteria
\end{abstract}


data. A set of thematic maps were produced, based on existing geological maps and freelyavailable ASTER Global DEM elevation data, using various geological information (i.e. lineaments and lithologies), geomorphometric indices (i.e. slope gradient, drainage density, stream frequency, and the topographic wetness index) and morphotectonic indices (i.e. amplitude of relief and stream length gradient) that highlight areas of neotectonic landscape deformation. The weights of the factors were determined using AHP and WLC. A neotectonic landscape deformation index (NLDI) is computed as the sum of the various weighted factors to provide a map of $N L D I$ distribution across the study region (western Crete). The main objective of this study was to analyse and map the intra-basin spatial variations in neotectonic landscape deformation: five classes, very low to very high, were determined. High to very high deformation zones are linked with known and newly detected active fault zones. The methodology could be developed into a low-cost technique for assessing seismic hazard, guiding disaster risk reduction activities. It can provide an alternative to the Interferometric Synthetic Aperture Radar (InSAR) approach for highlighting zones of neotectonic deformation, particularly in regions where dense vegetation or snow cover renders InSAR ineffective.

Keywords: Neotectonics; Multi-criteria decision analysis (MCDA); GIS; Morphotectonics 


\section{Introduction}

The geomorphological and morphotectonic study of drainage systems can provide useful indicators about the recent tectonic regime of a region. The development of geomorphic indices has led to the identification of areas deformed by recent tectonic processes (Bull and McFadden, 1977; Keller, 1986; Pérez-Peña et al., 2009). Such indices provide a useful tool to detect tectonically active regions that are being deformed by faults, affected by erosional processes or influenced by movements of crustal blocks (Burbank \& Anderson, 2001; Tsodoulos et al., 2008; Pedrera et al., 2009).

The data for these indices have traditionally been obtained from topographic maps and aerial photographs. In recent decades, the usefulness of geomorphic indices has become even greater due to greater availability of digital elevation models (DEMs), improved functionality of GIS and faster computer processing. The use of GIS aids the processing of data and speeds up the decision-making process (Malczewski, 2006 and references therein; Troiani and Della Seta, 2008).

This study examines some geomorphometric and morphotectonic indices that are useful for identifying areas of active tectonics. Geomorphometric indices can be used for the analysis of stream networks and drainage basins to delineate areas with neotectonic deformation (e.g. Abrahams, 1984; Ozdemir and Bird, 2009; Aher et al., 2014). In addition, there are many examples of morphotectonic indices being used to detect and characterize variations in active tectonics across a given landscape (e.g. Bull and McFadden, 1977; Ribolini and Spagnolo, 2008; Toudeshki and Arian, 2011). The 
calculation of morphotectonic indices has played a key role in determining local tectonic activity, particularly in identifying and mapping of fault-generated mountain fronts, or evaluating stream migration and identifying tilted or uplifted regions (Keller, 1986; Van der Beek et al., 2002; Silva et al., 2003).

This study carries out a multi-criteria decision analysis (MCDA) based on geomorphologic, geological and morphotectonic features, to detect areas of neotectonic landscape deformation and produce a map showing the distribution of that deformation. In MCDA a decision-maker has to choose several options or alternatives. Selecting an alternative depends on many characteristics (criteria) which are often contradictory: consequently the decision-maker might often have to be content with a compromise solution (Chakhar and Martel, 2003).

Spatial multi-criteria decision making usually consists of a set of feasible alternatives that are evaluated on the basis of multiple, conflicting and disproportionate evaluation criteria (Rinner and Malczewski, 2002; Boroushaki and Malczewski, 2008). Many spatial decision problems have been examined using GIS and MCDA (GIS-MCDA) (e.g. Laaribi et al., 1996; Chakhar and Martel, 2003; Drobne and Lisec, 2009). A GISMCDA approach integrates and transforms geographical data and value judgments to obtain overall assessment of the decision criteria (Malczewski, 1999, 2006). It has become an attractive method for spatial planning and management and can be considered as a tool for decision-makers, giving solutions to issues that need to consider several criteria (e.g. Joerin et al., 2001; Karnatak, et al., 2007; Chen et al., 2009). 
The tectonically active region of western Crete, Greece, was selected to test the GIS-based AHP, using a WLC, approach to assess neotectonics. The study region lies within the outer fore-arc of the largest and most active subduction zone in Europe, the Hellenic arc, which is characterized by high rates of tectonic activity and seismicity (e.g. Le Pichon et al., 1982; Kellletat, 1996), due to convergence between the African and Eurasian tectonic plates (Fig. 1) (McKenzie, 1978; Papazachos and Comninakis, 1978; Le Pichon et al., 1982). For example, the 21 July, 365 AD earthquake ( $M w 8.3-8.5)$, the so called "Early Byzantine Tectonic Paroxysm", produced co-seismic uplift up to $9 \mathrm{~m}$ on southwestern Crete (Thommeret et al., 1981; Stiros, 2001; Shaw et al., 2008). Crete has been tilted to the northeast (Fytrolakis, 1980), although neotectonic studies assume that separate tectonic blocks react independently to provide differential rates of uplift or subsidence across the island (Papanikolaou, 1988; Fassoulas and Nikolakakis, 2005).

\section{Review of geomorphometric and morphotectonic indices}

The geomorphic indices used to determine active tectonics typically identify how a fluvial drainage network reacts to the effect of tectonic activity. Those indices include: i) the transverse topographic symmetry factor; ii) mountain front sinuosity; iii) the streamlength gradient index and; iv) the valley floor width to valley height ratio (Bull and McFadden, 1977; Molin et al., 2004; Toudeshki and Arian, 2011). These indices are meant to evaluate the types of stream characteristics associated with neotectonic deformation, such as change of channel and valley gradient, or change of channel width and depth 
(Summerfield, 2000). There are other indices, such as the asymmetry factor and hypsometric parameters (both hypsometric integrals and hypsometric curves), which can characterize tectonic activity on a regional basin scale (e.g. Strahler, 1952; Hurtrez et al., 1999; El-Hamdouni et al., 2008).

Previous studies applying these indices revealed valuable information about tectonically active areas, such as the southwestern USA (Bull and McFadden, 1977; Rockwell et al., 1984; Keller, 1986), the Acambay graben in Mexico (Ramirez-Herrera, 1998), the Pacific coast of Costa Rica (Wells et al., 1988), the southeastern coast of Spain (Silva et al., 2003), the northern Apennines in Italy (Troiani and Della Seta, 2008) and central Greece (Tsodoulos et al., 2008). The analysis of these particular indices has a potential to reveal a more detailed evaluation of erosional processes, as well as the degree of active tectonics over an area (Keller and Pinter, 1996; Ramirez-Herrera, 1998; Azañón et al., 2012).

This study utilizes indices suitable for spatial distribution analysis. None of the aforementioned indices can provide detailed spatial distribution analysis within each basin except from the stream length gradient index $(S L)$ (Table 1). SL discriminates tectonic influence from lithological factors and detects local uplift, even in small drainage basins (Troiani and Della Seta, 2008). SL is sensitive to tectonic factors and has been used to examine drainage network development (Hack, 1973; Chen et al., 2003; Pérez-Peña et al., 2009).

The amplitude of relief index (Ar) (Table 1) represents the spatial distribution of active tectonics by evaluating the relative relief of a region, highlighting areas of uplift or 
subsidence (e.g. Ciccacci et al., 1988; Della Seta et al., 2004; Troiani and Della Seta, 2008). Ar is useful to assess active tectonics but it is only based on relative relief observations without considering any other parameters. Mapping the spatial distribution of active tectonics is thus a challenging objective. Some studies have evaluated a number of geomorphometric indices, on a drainage basin scale, to extract a general index for assessing active tectonics (e.g. El-Hamdouni et al., 2008; Alipoor et al., 2011; Selim, 2013). However, intra-basin variations in neotectonic landscape deformation were not assessed.

Calculation of $S L$ and $A r$ is not integrated with any other geological and geomorphological factors that characterize an area as tectonically active. Such a limitation raises the need for more detailed geomorphometric information to be extracted, integrated and spatially analysed for assessing active tectonics. Important geomorphological information can be extracted by various geomorphometric indices, using DEMs, such as drainage density $(D d)$, stream frequency $(F u)$, topographic wetness index $(T W I)$ and slope gradient $(S)$ (Table 1). These indices offer variable information and isolation of particular aspects can be associated with the presence of active tectonics over a region.

This study examines the association of some geomorphic indices with neotectonic landscape deformation. The relationship between $D d, F u$ and $S$ can indicate the dominant processes shaping a region. It is generally accepted that an increase in $S$ leads to decrease in $D d$ (Lin and Oguchi, 2004). The high values of $D d$ are associated with very gentle slopes (Kouli et al., 2007). Howard (1997) observed that $D d$ and $S$ correlate negatively in rapidly eroding areas but positively in slowly eroding areas, where hillslope processes are dominant. Comparison between spatially analysed maps of $D d$ and $F u$ can indicate 
variations in soil permeability across a region. High $D d$ and high $F u$ are associated with impervious rocks, which enhance erosion. On the other hand, low values of $D d$ and $F u$ are associated with permeable formations and steep rugged surfaces (Reddy et al., 2004). A study of two drainage basins in western Crete revealed that high $F u$ values occurred in linear patterns, parallel or sub-parallel to major tectonic lineaments, indicating that the drainage network was being developed under tectonic influence (Kouli et al., 2007).

The control exerted by local topography on the spatial distribution of soil moisture and surface saturation can be examined using TWI (Quinn and Beven, 1991). TWI could indicate fault-controlled relief features, notably linear depressions connecting headwater valleys, with fluvial erosion exploiting zones of structural weakness, as well as deeply incised V-shaped valleys dissecting mid-slopes, indicating a fluvial response to on-going uplift (Migon et al., 2013). In addition to the approaches outlined above for the extraction of spatial morphotectonic and geomorphometric information, geological information can also be important for the assessment of neotectonic landscape deformation. Bedrock type and lineament density $(L d)$ or lineament frequency $(L f)$ can be very useful for assessing tectonic and seismic activity (Ananaba and Anjakaiye, 1987).

There have been relatively few GIS-MCDA assessments of tectonically active terrain. According to El-Hamdouni et al. (2008), the arithmetic mean values of various drainage basin morphotectonic indices can provide a combined index for assessing tectonic activity. Alipoor et al. (2011) followed a different approach: instead of the arithmetic mean, they used AHP to assess the degree and weight of each morphotectonic index, for a representation of tectonic activity in drainage basins. However, this approach was limited to the classification of tectonic activity for entire drainage basins. This study uses a GIS- 
MCDA approach for a more detailed analysis, determining intra-basin spatial variations in neotectonic landscape deformation.

With GIS-MCDA, each GIS layer consists of criteria for assigning attribute values (Boroushaki and Malczewski, 2008). One of the fundamental classes of GIS decision rules is the weighted summation procedure (Janssen and Rietveld, 1990; O'Sullivan and Unwin, 2003; Malczewski and Rinner, 2005). The efficient use of MCDA in decision analysis depends on the selection of the order weights. AHP which is based on the weighted summation model, can be used to obtain the essential order weights (Saaty, 1977; Saaty and Vargas, 1991). There are two ways in which the AHP method can be used within the GIS environment. Initially, it can be used to determine the importance of weights associated with criterion map layers. Those weights can be aggregated with the layers, as in other weighted combination methods (Drobne and Lisec, 2009). This approach is of particular importance for spatial decision problems with a large number of criteria, which makes it difficult to complete pairwise comparisons of the criteria (Eastman et al., 1993; Marinoni, 2004). Later, the AHP method can be used to combine the priority for all levels of the hierarchical structure, including the level representing criteria. The major advantage of incorporating MCDA techniques into such procedures is that the analysts can make use of value evaluation judgments in GIS-based decision making procedures.

\section{Methodology}

\subsection{Criteria for assessing neotectonic landscape deformation}


There are many criteria for assessing neotectonic landscape deformation: morphotectonic, geomorphological and geological. Selective information, out of those criteria, can be associated with active tectonics. Such information can be provided in the form of thematic maps. The main morphotectonic indices for the identification of morphotectonic features are: i) amplitude of relief ( $A r)$ and ii) stream length-gradient (SL). The geomorphological criteria, not directly related to the identification of morphotectonic features are: i) slope gradient $(S)$, ii) the topographic wetness index $(T W I)$, iii) drainage density $(D d)$ and iv) stream frequency $(F u)$. The geological criteria are: i) lithology $(L t h)$, ii) lineament density $(L d)$ and iii) lineament frequency $(L f)$ (Table 1$)$.

The analysis and interpretation of the spatial distribution maps can highlight neotectonically active zones, with regard to the criteria provided by each extracted DEM derivative. Regions characterized by a specific range of classified values, can be linked to indications of neotectonic landscape deformation and are expected to be highlighted by the GIS-MCDA:

i) $\quad S$ being moderate to steep or very steep;

ii) high values of $\mathrm{Ar}$;

iii) low TWI values characterizing regions with major ridges, steep slopes and Vshaped valleys;

iv) areas with low $F u$ and low $D d$ values can be characterized by potentially high neotectonic landscape deformation; 
v) high values of $S L$ indicate abrupt changes of river gradients as a result of neotectonic control;

vi) lithological formations such as Neogene and Quaternary deposits are weak, unconsolidated lithologies that result in reduced seismic wave velocities, a corresponding increase in wave amplitude and increased seismic risk; and

vii) zones with high $L d$ and $L f$ to enhance discrimination of regions under the influence of neotectonic control.

The above information can be determined from the DEM derivatives and geological maps. This derived information is interpreted within MCDA to highlight the spatial distribution of neotectonic landscape deformation.

\subsection{Data preparation}

The main datasets in this study were extracted from the $30 \mathrm{~m}$ resolution ASTER Global DEM (ASTER G-DEM) (Fig. 2). The derived indices are $A r, S L, S, L d, L f, D d, F u$, TWI and Lth (Table 1). All data are re-projected to a $30 \times 30 \mathrm{~m}$ grid, with a standardized range of values (Boroushaki and Malczewski, 2008). The weights and rank values to the data layers and classes were assigned using AHP. Then using the weighted linear combination (WLC), their classes are multiplied with the corresponding weights and their values are summed up to produce a neotectonic landscape deformation map. 
$A r$ is a parameter that can be used to statistically examine orographic configuration (Della Seta et al., 2004) (Table 1). The spatial distribution of $A r$ indicates active or recent vertical displacements (Ciccacci et al., 1988; Ciotoli et al., 2003; Troiani and Della Seta, 2008). Ar was calculated based on the method of Della Seta et al. (2004) using the ASTER G-DEM as an input dataset. The relative relief was determined by subtraction of the $\mathrm{DEM}_{\max }$ (each output cell contains the maximum of the input cells that are encompassed by the extent of that cell) from the $\mathrm{DEM}_{\min }$ (each output cell contains the minimum of the input cells that are encompassed by the extent of that cell), within a grid of $1 \times 1 \mathrm{~km}$. The centroid points of each unit area were then used to extract the $A r$ values, with kriging as the interpolation method (Cressie, 1990; Della Seta et al., 2004).

$S L$ is the ratio of the change in elevation of the reach to the length of the reach, multiplied by the total length of the channel to the point where the index is being calculated (Hack, 1973; Keller, 1986; Toudeshki and Arian, 2011) (Table 1). Stream power can be related to this index, as the stream has the tendency to erode its bed and transfer sediment from the highest part of its drainage basin to the basin mouth (Keller and Pinter, 2002). This index represents the spatial distribution of stream gradient changes along the drainage network. High resolution ( $0.5 \mathrm{~m}$ pixel) colour imagery of western Crete is available via Google Earth for 2002-2009. Visual inspection of the Google Earth imagery was used to determine the ranges of stream channel widths in the drainage basins of the study region, augmented by walk-over surveys along $\sim 15 \mathrm{~km}$ of stream channels. The surveys showed that most of the stream channels have seasonal flow, with channel widths from 5 to $20 \mathrm{~m}$ and floodplain widths $<50 \mathrm{~m}$. The stream channels examined in this study are thus relatively small, so local within-channel processes such as bank erosion has a 
minimal impact on the index calculation. The drainage network was derived from the ASTER G-DEM, by filling the voids, using the D8 algorithm and the stream module in GIS free open source software (e.g. QGIS) to extract drainage networks (Maidment, 2002; Li, 2014 and references therein). By applying a threshold value to the flow accumulation outcome, as extracted from the ASTER G-DEM, a stream network can be delineated (Tarboton et al., 1991). A flow accumulation threshold value of $400 \mathrm{~m}^{2}$ provided the best fit for drainage network delineation (Fig. 1), which is confirmed by comparison with the channels and floodplain zones visible on satellite imagery (e.g. ASTER) and topographical maps. The relationships between tectonic activity, rock resistance and channel slope can be investigated with the $S L$ index. Large differences in the values of this index indicate zones of tectonic activity (Keller, 1986). This common morphotectonic index can represent the spatial distribution of stream gradient changes along the drainage network.

This study used the methodology proposed by Pérez-Peña et al. (2009) to calculate the normalized stream-length gradient $(S L k)$ in the main stream segments. Constant point spacing was used for the interpolation of values in a horizontal plane (Pérez-Peña et al., 2009): this allowed comparison with the related studies by Keller (1986). The calculated $S L k$ values were used to create an anomaly map, using a kriging statistical method based on a variogram model, providing better results than the spatial distribution of the $S L$ index (Pérez-Peña et al., 2009; Pedrera et al., 2009). The anomalous values were detected by following a cross-validation analysis, so that the tectonic controlled areas could be recognized (Goovaerts, 1997; Pérez-Peña et al., 2009).

$S$ shows maximum slope steepness based on the change in elevation between each cell and its neighbours (ESRI, 2003). Slope movements, in the case of tilting or uplift, are 
caused by tectonic activity. Such a process takes place essentially by means of slope gradient increase (Panizza, 1996).

$L d$ quantifies the total length of lineaments per $\mathrm{km}^{2}$ (Ananaba and Anjakaiye, 1987; Seleem, 2013). The lineaments used in this study were digitized from the faults recorded on the 1:50,000 scale geological map of western Crete (IGME, 1971) and from generation of shaded relief images with sun angles and azimuths produced from the ASTER G-DEM, aiding the recognition of regional lineaments and tectonic structures (Deffontaines et al., 1997; Chorowicz et al., 1999; Dewez, 2003). Illumination and shadow effects from different azimuths $\left(0^{\circ}, 45^{\circ}, 90^{\circ}, 135^{\circ}, 180^{\circ}, 225^{\circ}, 270^{\circ}\right.$ and $\left.315^{\circ}\right)$ with a sun elevation at $45^{\circ}$ were considered. The extracted lineaments lengths ranged from $\sim 300 \mathrm{~m}$ to $\sim 12 \mathrm{~km}$.

$L f$ quantifies the total number of lineaments per $\mathrm{km}^{2}$ (Briere and Scanlon, 2000; Dinesh et al., 2014). Statistical quantifications of $L d$ or $L f$ can be used to infer the relative severity of the tectonic regimes (Seleem, 2013). High values of $L d$ and $L f$ reveal regions undergoing high degrees of brittle rock fracturing, fault propagation and tectonic activity (Edet et al., 1998; Seleem, 2013). Relationships of $L d$ and $L f$ with tectonically deformed landscape zones were evaluated using the MCDA procedure.

$F u$ is the ratio of the total number of stream segments to the area of the drainage basin (Horton, 1945) (Table 1). GIS usage is crucial for the creation of distribution maps for $F u$. Through GIS free open source software, such as QGIS, kernel density was employed to compute $\mathrm{Fu}$ within a search area of $2 \mathrm{~km}$ as proposed by past studies of Zavoianu (1985 and references therein) and Kouli et al. (2007). The $F u$ maps indicate areas where fewer stream segments exist, due to neotectonic forces, such as uplift, which distort 
the development of the drainage system. When high $F u$ values occur and follow linear patterns, parallel or sub-parallel to the faults, that indicates the development of the stream segments under tectonic influence (Kouli et al., 2007).

$D d$ is the ratio of the total stream length to the area of the basin (Horton, 1945) (Table 1). GIS is useful for creating distribution maps of $D d$. High $D d$ values imply the presence of dissected terrain, while low $D d$ values indicate terrain with long hill slopes (Berger and Entekhabi, 2001; Awasthi et al., 2002).

TWI determines the spatial distribution of soil moisture and surface saturation with regard to the influence of topography, based on DEMs (Beven and Kirkby, 1979; Sorensen et al., 2005). This index is related to slopes, as water tends to accumulate at the foot of slopes. Relative soil moisture is thus dependant on the steepness of surrounding slopes and drainage accumulation. Low TWI values indicate high $S$ and low stream-flow accumulation (Conoscenti et al., 2008). TWI is helpful for detecting possible fault-controlled topographic features (Migon et al., 2013). Low values indicate: i) highly incised V-shaped valleys, ii) high relief surfaces with low moisture accumulation, or iii) longitudinal ridges. High values indicate: i) a low gradient surface with high moisture accumulation or ii) alluvial deposits (Schmidt and Persson, 2003; Migon et al., 2013). Topography is an important control of hydrological processes, so TWI can represent water distribution controlled by topography (Anderson and Kneale, 1982; Hjerdt et al., 2004). TWI is considered here to provide ancillary data to the MCDA procedure for the characterization and identification of regions that might be influenced by structural control, not to explain hydrological processes and soil moisture distribution. 
Lth is essential in the MCDA procedure because it discriminates between geological formations in terms of their response to the passage of seismic waves. Weak, unconsolidated lithologies result in reduced seismic wave velocities, and a corresponding increase in wave amplitude and seismic risk, while strong lithologies do not produce this amplification. The Geological Strength Index (GSI) was considered for the classification of the lithologies regarding their rock strength (Marinos and Hoek, 2000). Lithology is integrated with other factors in the MCDA procedure to assess the relative importance of this variable in relation to active tectonics. The lithological units were digitized from published 1:50,000 geological maps (IGME, 1971).

\subsection{Analytic hierarchy process (AHP)}

AHP is a popular heuristic method based on the additive weighting model (Banai, 1993; Wu, 1998; Zhu and Dale, 2001), which calculates the weighting factors associated with criterion map layers. That is achieved using a preference matrix where all identified relevant criteria are compared against each other with reproducible preference factors. AHP applications using GIS have become a common method of decision making because of its ability to integrate abundant heterogeneous data. The AHP method consists of three stages: (i) developing the AHP hierarchy, (ii) pairwise comparison of elements of the hierarchical structure, and (iii) constructing an overall priority rating. In the first stage, the decision problem is represented in a hierarchy that consists of the most important elements of the decision problem (i.e. the main goal of the problem, criteria and plans). At each level 
of the hierarchy in the second stage, a pairwise comparison of the matrices is performed based on their contribution to each other. At the last stage, the overall contribution of each factor to the main goal is calculated by an aggregation of the weighted average type (Saaty, 1980). In the context of this research, a typical level hierarchy of a goal, objectives and attributes have been considered in order to demonstrate the spatial analytic hierarchy procedure (Fig. 3), as proposed by Boroushaki and Malczewski (2008).

The AHP method has been used in two distinctive ways within the GIS environment. First, it was employed to derive the weights associated with attribute map layers, in a way similar to weighted additive combination methods. This approach is of particular importance for problems involving a large number of criteria, when it is impossible to perform a pairwise comparison of the selective criteria (Eastman et al., 1993). Second, the AHP principle was used to aggregate the priority for all levels of the hierarchy structure, including the level representing criteria. In this case, a relatively small number of criteria can be evaluated (Jankowski and Richard, 1994).

\subsection{Evaluation of criterion weights}

There are four basic techniques for the development of weights: pairwise comparison, ranking, rating and trade-off analysis methods (Malczewski, 1999). The pairwise comparison is the basic measurement mode employed in the AHP used in this research. It consists of three stages: i) develop a comparison matrix at each level of the hierarchy, ii) computation of the weights for each factor of the hierarchy, and iii) 
estimation of the consistency ratio. Within the pairwise comparison, the thematic map layers are given weighting values ranging from 1 to 9 , based on the level of importance (Saaty, 1980).

The nine thematic maps noted in Section 3.1 are used as primary data for the geological, geomorphological and morphotectonic analyses. The priority to be given to these criteria and their importance needs to be considered in the construction of the pairwise comparison matrix. For example, morphotectonic criteria are of higher importance, relative to the geomorphometric and geological criteria. By building a decision hierarchy, the evaluation of the various elements within the pairwise comparison matrix is achieved through the comparison of each possible criteria pair. Using AHP reduces the complexity of the decision problem into a series of pair-wise comparisons among competing attributes.

Once the pairwise comparison matrix is obtained, there is a need to summarize the preferences so that each factor can be assigned a proper relative importance. The consistency ratio $(C R)$ (Saaty, 1977) was used to check how consistent our results are. $C R$ is a ratio of the consistency index $(C I)$ to the random consistency index $(R I)$ :

$$
C R=C I / R I, \quad(1)
$$

where $C I=(\operatorname{Lmax}-n) /(n-1)$, with $\operatorname{Lmax}(\operatorname{Lambda} \max )$ being the maximum eigenvalue of the matrix, and $n$ is the matrix size. Saaty (1977) generated random matrices and computed their mean $C I$ value and defined it as $R I$.

$C R$ is useful for evaluating consistency in the pairwise comparison. If $C R<0.1$ then the ratio indicates a reasonable level of consistency in the pairwise comparison and 
the inconsistency is acceptable. However, if $C R>0.1$ then the value of the ratio is indicative of inconsistent judgments and our subjective judgements need to be revised. In the case of $C R<0.1$, the analyst needs to reconsider and revise the original values in the pairwise comparison matrix. As soon as the $C R$ value becomes acceptable, weights are assigned to each factor. The individual classes of each factor are ranked relatively to the importance of the information provided to the determination of the neotectonic landscape deformation. Then the classes are standardized to the same range of values for the completion of the final stage of MCDA procedure, which is WLC.

\subsection{Constructing an overall priority rating using WLC}

The final stage is to aggregate the relative weights of objectives and attribute levels to produce composite weights. This is done by means of a sequence of multiplications of the matrices of relative weights at each level of the hierarchy. Because the criteria values have different scales, a standardized approach of the factors is essential before their combination (Drobne and Lisec, 2009). The standardization is based on a number of classes of each factor regarding the importance of the information associated with active tectonics, such as the geomorphological, geological and morphotectonic features.

Determining the weight of each factor is achieved by ranking and rating. The factors are ranked, with the highest value being the most important and the lowest value the least important. Next, the rating is performed for each factor using percentiles. The factor with the highest ranking value acquires the highest percentage, while the lowest 
ranking value gets the lowest percentage. The equation for ranking values standardization is:

$$
N_{i, j}^{\prime}=\left(N_{i, j} / N_{j \max }\right) \times 100
$$

where $N^{\prime}{ }_{i, j}$ is the standardized rank value for the $i$-th class for the $j$-th factor, $N_{i, j}$ is the primary rank value, and $N_{\text {jmax }}$ is the maximum rank value.

Once the criterion scores for factors have been standardized and weights have been computed, the WLC technique is applied: it aggregates criteria to form a single final score of evaluation (Voogd, 1983; Malczewski, 2000; Ayalew et al., 2004). For WLC, the classes of the factors need to be standardized to a common numeric range, as described above. In the WLC method each weighted criterion from the pairwise comparison is multiplied by its standardized rank value weight and the results are summed. The indices used herein focus on zones of neotectonic landscape deformation, so the aforementioned results produce the following Neotectonic Landscape Deformation Index (NLDI):

$$
N L D I=\Sigma F w \times F r
$$

where $F w$ is the weight of each factor and $F r$ is the standardized rank value of each factor class.

After accomplishing the weighting-ranking process for the neotectonic landscape deformation values, within the 0-100 range, reclassification will be needed to make interpretation easier (primarily involving removal of micro-facets). The final classification will consist of five classes: very low, low, moderate, high and very high, based on the natural breaks in the frequency distribution (Ayalew et al., 2004). 


\section{Results}

\subsection{Evaluation of criterion weights}

The thematic spatial distribution maps for the drainage basins of western Crete used in this GIS-MCDA study are presented in Fig. 4. The spatial distribution maps were used for the AHP and the extraction of criteria weights by pairwise comparison matrices (Table 2). Then the classified ranking values and the standardized ratings for each thematic layer were defined, with the crucial information associated with the neotectonic landscape deformation characterized by the higher values. $C R$ was also calculated and considered for the consistency of the criteria of weights, as it has to be lower than 0.1 (Table 3): an acceptable consistency exists among the factors, where the value of $C R=0.067$.

Table 2 shows the final pairwise comparison matrix, based on the scale of Saaty (1980). The nine weight values $(0.22,0.21,0.15,0.15,0.07,0.07,0.06,0.04$ and 0.03$)$ were assigned respectively to the nine criteria, $S L k, A r, L d, L f, D d, F u, S, T W I$ and $L t h$, in decreasing order of importance (Table 3). The nine thematic maps are discriminated into morphotectonic, geomorphological and geological criteria. The extracted weights of criteria revealed that morphotectonic maps contribute a value of 0.43 to the final neotectonic landscape deformation map. The geomorphological criteria contribute a value of 0.24 . The geological factors contribute a value of 0.35 and lineament characteristics, 
associated with tectonic control, contribute a value of 0.3 . Lineaments and morphotectonic characteristics criteria, which primarily indicate neotectonic activity, contribute a relatively high value $(0.73)$ to the final neotectonic landscape deformation map.

\subsection{Constructing an overall priority rating using WLC}

The acquired criteria of weights by the pairwise comparison matrices are used here for the construction of an overall priority rating following the WLC procedure. Weights, rank values and standardized ratings of each factor are determined. The acquired information for each factor, highlighting the varying neotectonic attributes, is used in Eq. (3). The results of the neotectonic landscape deformation mapping are summarized in Fig. 5. The higher the values are, the more susceptible the area is to neotectonic landscape deformation: the "very low" class has values less than 24, "low" from 25 to 36, "moderate" from 37 to 46, "high" from 47 to 56 and "very high" above 57. The standardization is based on a number of classes of each factor regarding the importance of the information associated with active tectonics, such as the geomorphological, geological and morphotectonic features. The final neotectonic landscape deformation map highlights zones undergoing various degrees of neotectonic landscape deformation (Fig. 6).

\subsection{Validation of results}


Ground-based surveys were performed in the areas where the final neotectonic landscape deformation map indicated high to moderate or low degrees of neotectonic landscape deformation. Validation of the methodology was carried out through detailed geological field surveys of faults in those areas, examining the fault surfaces for indications of recent tectonic activity (e.g. slickenlines, freshness of exposures and sharpness of scarps). However, outcrops along active faults are likely to be obscured inherently by products of their activity, e.g. landslides and high-energy deposits, such as alluvial fans. The ground-based surveys found that the zones of high neotectonic landscape deformation, in the final neotectonic landscape deformation map (Fig. 6), were associated with fault outcrops, slickenlines, fault breccia and offset Quaternary deposits of alluvium and colluvium (Fig. 7).

In many instances the presence of slickenlines, best developed in limestones, is remarkably fresh, suggesting recent activity. One occurrence displays slickenlines preserved on a fault plane, in relatively erodible marls, which cuts the basal conglomerate of a raised beach deposit, confirming the active designation for this fault (Fig. 7). The age of these deposits has not been determined independently in the present study, but their fresh appearance, and widespread occurrence in western Crete, strongly suggests that they date from the last interglacial "Tyrrhenian" sea level of about $125 \mathrm{ka}$, which is widespread around the Mediterranean. There are numerous examples of fault truncation of these marine terraces in the study area, with tectonic uplift exceeding $50 \mathrm{~m}$ above present sea level. Other littoral features, such as marine notch, sea cave and beach rock assemblages also display fault truncation and uplift, particularly along the southern and western coasts of the study area. 
Walk-over surveys along the faults highlighted by our methodology, reveal further evidence for their "active" designation. This evidence includes fault juxtaposition of bedrock against young alluvial and colluvial sediments and, on slickenlined fault scarp faces, bands of increasing weathering aligned generally parallel to the ground surface, indicating incremental faulting-induced growth of the scarp.

\section{Discussion}

This study has presented a GIS-MCDA approach to predict zones with different degrees of neotectonic landscape deformation. Nine thematic maps formed the primary input data: the maps individually summarized geomorphological, geological and morphotectonic features. The analysis and interpretation of the nine maps yielded some associations of criteria that are indicative of neotectonic landscape deformation, notably the ones mentioned in Section 3.1.

A critical feature of producing and interpreting the final neotectonic landscape deformation map, was the determination of the criteria of weights and overall priority rating of the factors, based on the AHP and WLC, for the assessment of neotectonic landscape deformation (Fig. 2). The AHP reduces a complex decision problem into simpler decision approaches, for easier decision making. The use of pairwise comparisons for determining the weights of the criteria reduces complexity.

The advantage of pairwise comparison matrices, relative to other methods for determination of weights, is that the analyst can check the consistency of the weights by 
calculating the consistency ratio. This issue is not examined by other determination methods, where direct assignment of weights depends on the analyst's subjective judgement (Sener, 2004). The calculated $C R$ in this research was 0.067 , indicating good consistency of the selected factors within the pairwise comparison matrix.

Various geomorphic indices are apparently controlled by local tectonic activity. The findings in this study are in agreement with those in other studies, such as Keller and Pinter (1996), Silva et al. (2003), García-Tortosa et al. (2008) and Alipoor et al. (2011). Most of these studies examine particular geomorphic indices at specific sites such as a drainage basin or a mountain front. In many cases only a few indices, such as $S L$ and $A r$, have been spatially analysed to assess active tectonics (e.g. Della Seta et al., 2004; PérezPeña et al., 2009). Recent studies have attempted to use geomorphic indices by considering a GIS based summary index to spatially analyse the active tectonics of a region (e.g. ElHamdouni et al., 2008; Selim, 2013). They quantified several geomorphic indices to characterize active tectonics and provide a single index that highlights the degree of tectonic activity. Those studies took into account the whole basin area, not the more detailed intra-basin spatial variations in neotectonic landscape deformation considered in this study.

AHP is used in this research because it provides common techniques for decision making. Nonetheless, there might be some drawbacks. For example, the standardized factors of WLC reveal that the higher the score, the more suitable the location is for our purposes. There is no definitive threshold that allows allocation of areas to be chosen and areas to be excluded (Drobne and Lisec, 2009). Such facts suggest that some interrelationships might be hidden when using this methodology and it is likely to fail in 
recognizing some information. For this reason, the less low-cost fuzzy logic analytic hierarchy process (Fuzzy-AHP) or the ordered weighted averaging (OWA) approaches can be considered for further research and could provide an extension to the conventional map combination methods.

Fieldwork by the authors has verified the zones of neotectonic landscape deformation predicted by this methodological framework, ranging from minimal tectonic activity to active faults. Active faults create a 'constructive' tectonic and geomorphic signature along their strike, generally overwhelming 'destructive' processes such as erosion and deposition. One of the most known tectonically active faults in western Crete is the Keras fault, previously producing large magnitude earthquakes (Mouslopoulou et al., 2001), which our ground surveys showed to be characterized by a high degree of neotectonic landscape deformation (Fig. 7). In the case of less active faults, the balance between the opposing landscape-forming processes is struck differently, with constructional tectonic signatures being more subdued, particularly when considering smaller-scale and more ephemeral fault features, such as fresh slickenlines and small scarps in unconsolidated deposits. Consequently, low activity faults are likely to be revealed by large-scale topographic and drainage lineaments, but lack smaller scale features when traced along strike. Such regions are highlighted by the lower activity zones in the final neotectonic landscape deformation map of this study (Fig. 7).

This study has assessed potential neotectonic landscape deformation zones, providing an innovative, low-cost, set of geoinformatic techniques. This approach is particularly useful: i) where the current tectonic regime produces active faults, which inherently produce active erosion and deposition that obscures the surface expression of 
those faults; ii) where outcrops that expose active faults are rare and active faults may not be depicted on maps; and iii) where no sophisticated systems exist for monitoring and assessing current tectonic regimes.

InSAR can highlight zones of ground deformation, including tectonic activity (Massonet et al., 1993). However, regions with dense vegetation cover or seasonal snow cover produce InSAR interferograms with low coherence, resulting in decorrelation between interferograms and rendering them useless for the monitoring of ground deformation (e.g. Hassen, 2001; Hole et al., 2007). The geomorphometric GIS-MCDA methodology presented here, using freely-available ASTER G-DEM data or SRTM DEM data, could therefore be a valuable tool for seismic hazard assessment and disaster risk reduction in tectonically active regions that are not suited to InSAR analysis.

\section{Conclusions}

The methodology presented uses geomorphometric analyses to provide rapid evaluations of tectonically active regions and potential seismic risks. Thematic maps of geomorphometric, morphotectonic and geological information were integrated to highlight zones of neotectonic landscape deformation. Those thematic maps were evaluated through a GIS-MCDA approach using the AHP and WLC. Through that approach, the isolation of the crucial information relevant to neotectonic landscape deformation was determined by evaluating the various thematic maps. The information was then used to calculate the NLDI index to produce a map showing the spatial distribution of neotectonic landscape 
deformation. The map highlights intra-basin spatial variations of neotectonic landscape deformation, rather than the coarser whole-basin representations of previous studies.

The findings demonstrate how geomorphometrics, linked with GIS, can highlight zones of neotectonic landscape deformation, providing target areas for ground surveys aiming to verify the presence of active faults. The methodology could be a low-cost alternative to InSAR for detecting zones of neotectonic deformation, particularly in woodland areas or regions with seasonal snow cover. Finally, the methodology is a potentially useful tool for regional planners and decision-makers involved with seismic hazard assessment and disaster risk reduction.

\section{Acknowledgements}

We thank anonymous reviewers for useful comments on an earlier draft of this paper. Many thanks to J.V. Pérez-Peña and Marta Della Seta for guidance on calculating the normalized stream length gradient and amplitude of relief index respectively. This project was implemented through the Operational Program "Education and Lifelong Learning", Action Archimedes III, co-financed by the European Union (European Social Fund) and Greek national funds (National Strategic Reference Framework 2007-2013), project title: Interdisciplinary study for exploring, understanding and management of groundwater resources. Pilot field investigation North-Western and Central Crete (AQUADAM). 


\section{References}

Abrahams, A.D., 1984. Channel networks: a geomorphological perspective. Water Resour. Res, 20, pp.161-188.

Aher, P.D., Adinarayana, J., Gorantiwar, S.D., 2014. Quantification of morphometric characterization and prioritization for management planning in semi-arid tropics of India: a remote sensing and GIS approach. J. Hydrol., 511, pp 850-860.

Alipoor, R., Poorkermani, M., Zare, M., El-Hamdouni, R., 2011. Active tectonic assessment around Rudbar Lorestan dam site, High Zagros Belt (SW of Iran). Geomorphology 128, pp. 1-14.

Ananaba, S.E. and Anjakaiye, D.E., 1987. Evidence of tectonic control of mineralization in Nigeria from lineament density analysis a Landsat-study. Int. J. of Remote Sens., Volume 8, Issue 10, pp. 1445-1453.

Anderson, M.G. and Kneale, P.E., 1982. The influence of low-angled topography on hillslope soil-water convergence and stream discharge. Journal Hydrol. 57, pp. 65-80.

Awasthi, K.D., Sitaula, B.K., Singh, R.B.R., Bajacharaya, M., 2002. Land-use change in two Nepalese watersheds: GIS and geomorphometric analysis. Land Degrad. Develop. 13, pp. 495-513.

Ayalew, L., Yamagishi, H., Ugawa, N., 2004. Landslide susceptibility mapping using GISbased weighted linear combination, the case in Tsugawa area of Agano River, Niigata Prefecture, Japan. Landslides 1, pp. 73-81.

Azañón, J.M., Pérez-Peña, J.V., Giaconia, F., Booth-Rea, G., Martínez-Martínez, J.M., Rodríguez-Peces, M.J., 2012. Active tectonics in the central and eastern Betic Cordillera through morphotectonic analysis: the case of Sierra Nevada and Sierra Alhamilla. J. of Iber. Geol. 38, pp. 225-238.

Banai, R., 1993. Fuzziness in geographic information systems: contributions from the analytic hierarchy process. International J. Geogr. Inform. Syst. 7 (4), pp. 315-329.

Berger, K.P. and Entekhabi, D., 2001. Basin hydrologic response relations to distributed physiographic descriptors and climate. J. of Hydrol. 247, pp. 169-182.

Beven, K.J. and Kirkby, M.J., 1979. A physically based, variable contributing area model of basin hydrology. Hydrol. Sci.Bull. 24, pp. 43-69.

Bohnhoff, M., Makris, J., Papanikolaou, D., Stavrakakis, G., 2001. Crustal investigation of the Hellenic subduction zone using wide aperture seismic data. Tectonophysics, 343, 3-4, pp. 239-262.

Boroushaki, S. and Malczewski, J., 2008. Implementing an extension of the analytical hierarchy process using ordered weighted averaging operators with fuzzy quantifiers in ArcGIS. Comput. Geosci. 34, pp. 399-410.

Briere, P.R. and Scanlon, K.M., 2000. Lineaments and lithology derived from a sidelooking airborne radar image or Puerto Rico. In: Puerto Rico-marine sediment database, 
terrestrial and sea-floor imagery and tectonic interpretations: U.S. Geological Survey Open-File Report 00-006.

Bull, W. and McFadden, L., 1977. Tectonic geomorphology north and south of the Garlock Fault, California. In: Doehring, D.O. (Ed.), Geomorphology in Arid regions. Publications in Geomorphology, State University of New York at Bingamton, pp. 115-139.

Burbank, D.W. and Anderson, R.S., 2001. Tectonic Geomorphology. Blackwell Science, Malden, Massachusetts, 274pp.

Chakhar, S. and Martel, J.M., 2003. Enhancing geographical information systems capabilities with multi-criteria evaluation functions. J. Geogr. Inf. Decis. Anal. 7, pp. 4771.

Chen, Y.C., Sung, Q.C., Cheng, K.Y., 2003. Along-strike variations of morphotectonic features in the Western Foothills of Taiwan: tectonic implications based on stream-gradient and hypsometric analysis. Geomorphology 56, pp. 109-137.

Chen, Y., Khan, S., Paydar, Z., 2009. To retire or expand? A fuzzy GIS-based spatial multi-criteria evaluation framework for irrigated agriculture. Irrig. Drain., 59 (2), pp. 174188.

Chorowicz, J., Dhont, D., Gundogdu, N., 1999. Neotectonics in the eastern North Anatolian fault region (Turkey) advocates crustal extension: mapping from SAR ERS imagery and digital elevation model. J. Struct. Geol. 21, pp. 511-532.

Ciccacci, S., De Rita, D., Fredi, P., 1988. Geomorfologia quantitativa e morfotettonica dell'area di Morlupo-Castelnuovo di Porto nei Monti Sabatini (Lazio). Supplemento di Geografia Fisica e Dinamica Quaternaria I, pp. 197-206.

Ciotoli, G., Della Seta, M., Del Monte, M., Fredi, P., Lombardi, S., Lupia Palmieri, E., Pugliese, F., 2003. Morphological and geochemical evidence of neotectonics in the volcanic area of Monti Vulsini (Latium,Italy). Quat. Int. 101-102, pp. 103-113

Conoscenti, C., Di Maggio, C., Rotigliano, E., 2008. GIS analysis to assess landslide susceptibility in a fluvial basin of NW Sicily (Italy), Geomorphology 94, pp. 325-339.

Cressie, N., 1990. The origins of kriging. Math. Geol., 22, pp. 239-252.

Deffontaines, B., Lacombe, O., Angelier, J., Chu, H.T., Mouthereau, F., Lee, C.T., Deramond, J., Lee, J.F., Yu, M.S., Liew, P.M., 1997. Quaternary transfer faulting in the Taiwan foothills: evidence from a multisource approach. Tectonophysics 274, pp. 6182.

Della Seta, M., Del Monte, M., Fredi, P., Lupia Palmieri, E., 2004. Quantitative morphotectonic analysis as a tool for detecting deformation patterns in soft-rock terrains: a case study from the southern Marches, Italy. Géomorphologie: relief, processus, environnement, 2004, n 4, pp. 267-284. 
Dewez, T. J. B., 2003. Geomorphic markers and digital elevation models as tools for tectonic geomorphology in central Greece. PhD thesis, Department of Geography and Earth Sciences, Brunel University, 173pp.

Dinesh, A.C., Markose Vipin, J., Jayappa, K.S., 2014. Linfo- a visual basic program for lineament density, frequency and intersection density analysis. Earth Sci. Inform. 7, pp. 197-203.

Drobne, S. and Lisec, A., 2009. Multi-attribute decision analysis in GIS: weighted linear combination and ordered weighted averaging. Informatica 33, pp. 459-474.

Eastman, J.R., Kyem, P.A.K., Toledano, J., Jin, W., 1993. GIS and Decision Making. United Nations Institute for Training and Research (UNITAR). The Clarks Labs for Cartographic Technology and Geographic Analysis. Clark University, Worcester, MA, USA. Explorations in Geographic Informations Systems Technology 4, 112pp.

Edet, A.E., Okereke, C.S., Teme, S.C., Esu, E.O., 1998. Application of remote sensing data to groundwater exploration: a case study of the Cross River State, southeastern Nigeria. Hydrogeol. J. 6, pp. 393-404.

El-Hamdouni, R., Irigaray, C., Fernández, T., Chacón, J., Keller, E.A., 2008. Assessment of relative active tectonics, southwest border of the Sierra Nevada (southern Spain). Geomorphology 96, pp. 150-173.

ESRI, 2003. ArcGis Desktop Help, in ArcMap utility.

Evans, I.S., 1979. An integrated system of terrain analysis and slope mapping. Final Report on Grant DA-ERO- 591-73-G0040. University of Durham, England, 192pp.

Fassoulas, C. and Nikolakakis, M., 2005. Landscape response to the tectonic uplift of Crete, Greece. Bulletin of the Geological Society of Greece vol XXXVII, pp. 201-217.

Fytrolakis, N., 1980. The geological structure of Crete: Problems, observations and conclusions. Habil. Thesis, Nat. Techn. Univ. Athens, 143pp.

García-Tortosa, F.J., Alfaro, P., Galindo-Zaldívar, J., Gibert, L., López-Garrido, A.C., Sanz de Galdeano, C., Ureña, M., 2008. Geomorphologic evidence of the active Baza Fault (Betic Cordillera, South Spain). Geomorphology 97, pp. 374-391.

Goovaerts, P., 1997. Geostatistics for Natural Resources Evaluation. Oxford University Press: New York, 483pp.

Hack, J., 1973. Stream profile analysis and stream gradient index, U. S. Geol. Surv. J. Res. 1, pp. 421-429.

Hassen, R.F., 2001. Radar interferometry, data interpretation and error analysis. Dordrecht: Kluwer Academic Publishers, 328pp.

Hjerdt, K.N, McDonell, J.J., Seibert, J., Rodhe, A., 2004. A new topographic index to quantify downslope controls on local drainage. Water Resour. Res. 40, W05602, pp. 1-6. 
Hole, J.K., Bromley, C., Stevens, N.F., Wadge, G., 2007. Subsidence in the geothermal fields of the Taupo Volcanic Zone, New Zealand from 1996 to 2005 measured by InSAR. J. Volc. Geother. Res., 166(3-4), pp. 125-146.

Horton, R.E. 1945. Erosional Development of Streams and their drainage basins; hydrophysical approach to quantitative morphology. Geol. Soc. Am. Bull., 56, pp. 275-370.

Howard, A.D., 1997. Badland morphology and evolution: interpretation using a simulation model. Earth Surf. Process. Landf, 22, pp. 211-227.

Hurtrez, J.E., Sol, C., Lucazeau, F., 1999. Effect of drainage area on hypsometry from an analysis of small-scale drainage basins in the Siwalik hills (central Nepal), Earth Surf. Process Landf., 24, pp. 799-808.

IGME, 1971. Geological Map of Greece, western Crete sheets. Athens: Institute of Geology and Mineral Exploration. Scale: 1:50,000.

Jankowski, P. and Richard, L., 1994. Integration of GIS-based suitability analysis and multicriteria evaluation in a spatial decision support system for route selection, Environment and Planning B: Planning and Design 21, pp. 323-340.

Janssen, R. and Rietveld, P., 1990. Multicriteria analysis and geographical information systems: an application to agricultural land use in the Netherlands. In Geographical Information Systems for Urban and Regional Planning, edited by H.J. Scholten, and JC.H. Stillwell (Eds), pp. 129-139.

Joerin, F., Theriault, M., Musy, A., 2001. Using GIS and outranking multicriteria analysis for land-use suitability assessment. Int. J. Geogr. Inf. Sci. 15, pp. 153-174.

Karnatak, H.C., Saran, S., Bhatia, K., Roy, P.S., 2007. Multicriteria spatial decision analysis in Web GIS environment. GeoInformatica 11, pp. 407-429.

Keller, E.A., 1986. Investigation of active tectonics: Use of surficial earth processes. In: Wallace, R.E. (Ed.), Active Tectonics. Studies in Geophysics. The National Academies Press, Washington, DC, pp. 136-147.

Keller, E.A. and Pinter, N., 1996. Active Tectonics (Earthquakes, Uplift and Landscape). Prentice-Hall Inc., New Jersey, 339pp.

Keller, E. A. and Pinter, N., 2002. Active Tectonics: Earthquakes and Landscape. Second Edition. Prentice-Hall: Upper Saddle River, New Jersey, 362pp.

Kelletat, D., 1996. Perspectives in coastal geomorphology of western Crete, Greece. Zeitschrift füer geomorphologie N. F., Supplement Band 102, pp. 1-19.

Kouli, M., Vallianatos, F., Soupios, P., Alexakis, D., 2007. GIS-based morphometric analysis of two major watersheds, western Crete, Greece, Journal of Environmental Hydrology 15, pp. 1-17. 
Laaribi, A., Chevallier, J.J., Martel, J.M., 1996. A spatial decision aid: a multicriterion evaluation approach, Computers and Urban Systems 20, pp. 351-366.

Le Pichon, X., Lybéris, N., Angelier, J., Renard, V., 1982. Strain distribution over the east Mediterranean Ridge: A synthesis incorporating new SEA-BEAM data: Tectonophysics 86, pp. 243-274.

Li, Z., 2014. Watershed modeling using arc hydro based on DEMs: a case study in Jackpine watershed. Environmental Systems Research 3, 11pp.

Lin, Z., and Oguchi, T., 2004. Drainage density, slope angle, and relative basin position in Japanese bare lands from high-resolutions DEMs. Geomorphology, 63, pp. 159-173.

Maidment, D., 2002. Arc Hydro: GIS for Water Resources. Redlands, CA, USA: ESRI Press, Volume 1, 203pp.

Malczewski, J., 1999. GIS and Multicriteria Decision Analysis, John Wiley and Sons, Toronto, 392pp.

Malczewski, J., 2000. On the use of Weighted Linear Combination method in GIS: common and best practise approaches. Trans. GIS 4, pp. 5-22.

Malczewski, J. and Rinner, C., 2005. Exploring multicriteria decision strategies in GIS with linguistic quantifiers: a case study of residential quality evaluation. Journal of Geographical System 7, pp. 249-256.

Malczewski, J., 2006. GIS-based multicriteria decision analysis: a survey of the literature. Int. J. Geogr. Inf. Sci. 20 (7), pp. 703-726.

Marinoni, O., 2004. Implementation of the analytical hierarchy process with VBA in ArcGIS. Comput. Geosci. 30 (6), pp. 637-646.

Marinos, P. and Hoek, E., 2000. GSI: a geologically friendly tool for rock mass strength estimation. In: Proceedings GeoEng2000, Melbourne, Australia, pp. 1422-1442.

Massonnet, D., Rossi, M., Carmona, C., Adragna, F., Peltzer, G., Feigl, K., Rabaute, T., 1993. The displacement field of the Landers earthquake mapped by radar interferometry. Nature 364, pp. 138-142.

McKenzie, D.P., 1978. Some remarks on the development of sedimentary basins. Earth Panet. Sci. Lett., 40, pp. 23-32.

Migon, P., Kasprzak, M., Traczyk, A., 2013. How high- resolution DEM based on airborne LiDAR helped to reinterpret landforms - examples from the Sudetes, SW Poland. Landform Anal., Vol. 22, pp. 89-101.

Molin, P., Pazzaglia, F.J., Dramis, F., 2004, Geomorphic expression of active tectonics in a rapidly-deforming forearc, Sila massif, Calabria, southern Italy. Am. J. Sci. 304, pp. 559589. 
Mouslopoulou, V., Andreou, C., Atakan, K., Fountoulis, I., 2001. Paleoseismological investigations along the Kera Fault Zone, Western Crete: Implications for Seismic Hazard Assessment. In: Proc. Of $9^{\text {th }}$ Congress of Geol. Soc. Greece, Bull. Geol. Soc. Greece, $t$. XXXIV/4, pp. 1531-1537.

O’Sullivan, D. and Unwin, D. 2003. Geographic Information Analysis. Wiley, Hoboken, NJ, 436pp.

Ozdemir, H. and Bird, D., 2009. Evaluation of morphometric parameters of drainage networks derived from topographic maps and DEM in point of floods. Environ. Geol., 56, pp. 1405-1415.

Panizza, M., 1996. Environmental Geomorphology. Elsevier Science, 288pp.

Papanikolaou, D., 1988. Introduction to the geology of Crete. In: IGCP, No 276, Fieldguide Book, 36 pp.

Papazachos, B.C. and Comninakis, P.E., 1978. Deep structure and tectonics of the Eastern Mediterranean. Tectonophysics, 33, pp. 285-296.

Pedrera, A., Pérez-Peña, J.V., Galindo-Zaldívar, J., Azañón, J.M., Azor, A., 2009. Testing the sensitivity of geomorphic indices in areas of low-rate active folding (eastern Betic Cordillera, Spain). Geomorphology 105, pp. 218-231.

Pérez-Peña, J.V., Azañón, J.M., Azor, A., Delgado, J., González-Lodeiro, F., 2009. Spatial analysis of stream power using GIS: SLk anomaly maps. Earth Surf. Process. Landf. 34, pp.16-25.

Quinn, P. F. and Beven, K. J., 1991. The prediction of hillslope flow parths for distributed hydrological modelling using digital terrain models. Hydrol. Process. 5, pp.59-79.

Ramírez-Herrera, M.T., 1998. Geomorphic assessment of active tectonics in the Acambay Graben, Mexican volcanic belt. Earth Surf. Process. Landf. 23, pp.317-332.

Reddy, G.P. Obi, Maji, A.K., Gajbhiye, K.S., 2004. Drainage morphometry and its influence on landform characteristics in a basaltic terrain, Central India - a remote sensing and GIS approach. International Journal of Applied Earth Observation and Geoinformation 6, pp 1-16.

Ribolini, A. and Spagnolo, M., 2008. Drainage network geometry versus tectonics in the Argentera Massif (French-Italian Alps). Geomorphology 93, pp. 253-266.

Rinner, C. and Malczewski, J., 2002. Web-enabled spatial decision analysis using ordered weighted averaging. Journal of Geographical Systems 4, pp. 385-403.

Rockwell, T.K., Keller, E.A., Johnson, D.L., 1984. Tectonic geomorphology of alluvial fans and mountain fronts near Ventura, California. In: Morisawa, M., Hack, T.J. (Eds.), Tectonic Geomorphology. Publ. in Geomorphology, State University of New York, Binghamton, pp. 183-207. 
Saaty, T.L., 1977. A scaling method for priorities in hierarchical structures. J. Math. Psychol. 15, pp. 231-281.

Saaty, T.L, 1980. The Analytic Hierarchy Process. McGraw Hill International, 287p.

Saaty, T.L. and Vargas, L.G., 1991. Prediction, Projection and Forecasting. Boston: Kluwer Academic, 254pp.

Schmidt, F. and Persson, A., 2003. Comparison of DEM data capture and topographic wetness indices. Preci Agric 4, pp. 179-192.

Seleem, T.A., 2013. Analysis and tectonic Implication of DEM-derived structural lineaments, Sinai Peninsula, Egypt, International Journal of Geosciences 4, pp. 183-201.

Selim, H.H., 2013. Tectonics of the buried Kirklareli Fault, Thrace Region, NW Turkey. Quat. Int., 312, pp 120-131.

Sener, B., 2004. Landfill site selection by using Geographical Information Systems. Thesis for the degree of Master of Science in geological engineering, Graduate school of natural and applied sciences of Middle East technical university, 114pp.

Shaw, B., Ambraseys, N.N., England, P.C., Floyd, M.A., Gorman, G.J., Higham, T.F. G., Jackson, J.A., Nocquet, J.M., Pain, C.C., Piggott, M.D., 2008. Eastern Mediterranean tectonics and tsunami hazard inferred from the AD 365 earthquake: Nature Geoscience 1, pp. 268-276.

Silva, P., Goy, J., Zazo, C., Bardaji, T., 2003. Fault-generated mountain fronts in southeast Spain: geomorphologic assessment of tectonic and seismic activity. Geomorphology, 50, pp. 203-225.

Sorensen, R., Zinko, U., Seibert, J., 2005. On the calculation of the topographic wetness index: evaluation of different methods based on field observations. Hydrol. Earth Syst. Sci. Discuss. 2, pp. 1807-1834.

Stiros, S.C., 2001. The AD 365 Crete earthquake and possible seismic clustering during the fourth to sixth centuries $\mathrm{AD}$ in the eastern Mediterranean: a review of historical and archaeological data: Journal of Structural Geology 23, pp. 545-562.

Strahler, A.N., 1952. Hypsometric (area-altitude) analysis of erosional topography. Geol. Soc. Am. Bull., 63, pp. 1117-1142.

Summerfield, M.A., 2000. Geomorphology and Global Tectonics. John Wiley \& Sons. $386 \mathrm{pp}$.

Tarboton, D. G., Bras, R. L., Rodriguez-Iturbe, I., 1991. On the Extraction of Channel Networks from Digital Elevation Data. Hydrol. Process. 5, pp. 81-100.

Thommeret, J., Thommeret, Y., Laborel, J., Montaggioni, L.F., Pirazzoli, P.A., 1981. Late Holocene shoreline changes and seismo-tectonic displacements in western Crete (Greece). Z. Geomorphol. 40, pp. 127-149. 
Toudeshki, V.H. and Arian, M., 2011. Morphotectonic analysis in the Ghezel Ozan River Basin, NW Iran. Journal of Geography and Geology 3, pp. 258-265.

Troiani, F. and Della Seta, M., 2008. The use of the stream length-gradient index in morphotectonic analysis of small catchments: a case study from Central Italy. Geomorphology 102, pp. 159-168.

Tsodoulos, I.M., Koukouvelas, I.K., Pavlides, S., 2008. Tectonic geomorphology of the easternmost extension of the Gulf of Corinth (Beotia, Central Greece). Tectonophysics, 453, pp. 211-232.

Van der Beek, P., Champel, B., Mugnier, J.L., 2002. Control of detachment dip on drainage development in regions of active fault propagation folding. Geology 30, pp. 471474.

Voogd, H., 1983. Multicriteria Evaluation for Urban and Regional Planning, Pion Ltd, London, 367pp.

Wells, S.G., Bullard, T.F., Menges, T.M., Drake, P.G., Karas, P.A., Kelson, K.I., Ritter, J.B., Wesling, J.R., 1988. Regional variations in tectonic geomorphology along segmented convergent plate boundary, Pacific coast of Costa Rica. Geomorphology 1, pp. 239-265.

Wu, F., 1998. SimLand: a prototype to simulate land conversion through the integrated GIS and CA with AHP-derived transition rules. Int. J. Geogr. Inf. Sci. 12, pp. 63-82.

Zavoianu, I., 1985. Morphometry of Drainage Basins (Developments in Water Science, 20). Elsevier, Amsterdam, 238pp.

Zhu, X. and Dale, A.P., 2001. JavaAHP: a Web-based decision analysis tool for natural resource and environmental management. Environ. Model. Softw. 16, pp. 251-262. 


\section{Tables/Figures:}

Table 1 Geomorphic parameters formulas and supplementary datasets used in this study, description and applicability.

Table 2 Matrix of weights evaluation with pairwise comparisons in analytic hierarchy process.

Table 3 Calculations extracted by analytic hierarchy process for criteria weights and consistency ratio. An acceptable consistency exists among the factors as the value of $\mathrm{CR}=$ 0.067 , not exceeding value of 0.1 .

Fig. 1 Location of the Aegean region with the major tectonic regime characteristics (modified from Bohnhoff et al., 2001) and the study area (square box) with the examined drainage basins and drainage network on the right image.

Fig. 2 Flow chart showing the data sets and methodological framework for the neotectonic landscape deformation analysis.

Fig. 3 Pair-wise comparison between the factors, with the individual analytic hierarchy and weighted linear combination sub-procedures.

Fig. 4 Thematic map layers to be used in the GIS MCDA approach for the western Crete drainage basins: a) $A r$; b) $S L k$; c) $S$; d) $L d$; e) $L f$; f) $T W I$; g) $D d$; h) $F u$ and; i) $L t h$.

Fig. 5 Natural breaks in the frequency distribution histogram of the values are considered for the grouping.

Fig. 6 Neotectonic landscape deformation map of western Crete, overlain on a Landsat ETM+ TM8 panchromatic band. The darker zones indicate the highest degree of neotectonic landscape deformation.

Fig. 7 Map set illustrating the fieldwork visits for the validation of the neotectonic landscape deformation. (a) Neotectonic landscape deformation map with locations of ground truthing surveys (1 to 4); (b) Location 1: Ground truthing of E-W striking fault plane that offsets young deposits; fault breccia and slickenlines are exposed: Fault plane with an NE-SW strike of $80^{\circ}$ and a dip of $67^{\circ}$ to north. Oblique slip is recorded by slickenlines; (c) Location 1: Slickenlines identified within the fault plane with a strike of $80^{\circ}$; (d) Location 2: Keras active fault overview; (e) Location 2: Keras active fault plane; (f) Location 3: fault bounded sequence of marine notches and caves, beginning at $\sim 9 \mathrm{~m}$; (g) Location 3: en echelon ENE-WSW fault set, both normal and reverse slip; massive white limestone in hanging wall, while footwall in sheared shaley limestone and, further east, buff marls; (h-i) Location 4: areas of "low" neotectonic landscape deformation (e.g. Kandanos), characterised by alluvial deposits and not a rough terrain. 
Table 1. Geomorphic parameters formulas and supplementary datasets used in this study, description and applicability.

\begin{tabular}{|c|c|c|c|c|}
\hline Indices & Formula & Description & Category & Bibliography \\
\hline $\begin{array}{l}\text { Amplitude relief } \\
(A r)\end{array}$ & & $\begin{array}{l}\text { The spatial distribution of the maximum difference in elevation within } \\
\text { unit areas of } 1 \mathrm{~km}^{2} \text {. A parameter that can be used for the statistically } \\
\text { orographic configuration of the study area in order to determine fluvial } \\
\text { erosion. Provides information associated with recent vertical } \\
\text { displacements of uplifted or subsidence blocks. }\end{array}$ & $\begin{array}{l}\text {-Tectonics/seismicity } \\
\text {-Flooding } \\
\text {-Erosion }\end{array}$ & Ciccacci et al.,1988 \\
\hline $\begin{array}{l}\text { Stream length } \\
\text { gradient (SL) }\end{array}$ & $\begin{array}{l}S \boldsymbol{S}=(\Delta \boldsymbol{H} / \Delta \boldsymbol{L}) \times \boldsymbol{L}, \\
\text { where } \Delta H \text { is the height increase, } \Delta L \\
\text { the horizontal distance corresponding } \\
\text { in each case to } \Delta H \text {, and } \mathrm{L} \text { the } \\
\text { accumulated length from the starting } \\
\text { point to the middle point of the } \\
\text { interval. }\end{array}$ & $\begin{array}{l}\text { The ratio of the change in elevation of the reach to the length of the } \\
\text { reach multiplied with the total length of the channel from the point of } \\
\text { interest where the index is being calculated. Abrupt changes in the } \\
\text { gradient of river can be associated with active tectonics. }\end{array}$ & $\begin{array}{l}\text {-Tectonics/seismicity } \\
\text {-Landslide }\end{array}$ & Hack, 1973 \\
\hline $\begin{array}{l}\text { Drainage } \\
\text { density }(D d)\end{array}$ & $\begin{array}{l}D \boldsymbol{d}=\boldsymbol{\Sigma} \boldsymbol{L} / \boldsymbol{A} \text {, } \\
\text { where } \Sigma L \text { is the total length of all the } \\
\text { ordered streams and } A \text { is the area of } \\
\text { the basin. }\end{array}$ & $\begin{array}{l}\text { The ratio of the total stream length to the area of the basin. The } \\
\text { drainage density reveals information regarding surface runoff } \\
\text { potential, ground surface steepness, the degree of landscape dissection, } \\
\text { rock permeability and resistance to erosion. }\end{array}$ & $\begin{array}{l}\text {-Tectonics/seismicity } \\
\text {-Flooding } \\
\text {-Landslide } \\
\text {-Erosion }\end{array}$ & Horton, 1945 \\
\hline $\begin{array}{l}\text { Stream } \\
\text { frequency }(F u)\end{array}$ & $\begin{array}{l}F u=N / A, \\
\text { where } \mathrm{N} \text { is the total number of stream } \\
\text { segments and } \mathrm{A} \text { is the area of the } \\
\text { basin. }\end{array}$ & $\begin{array}{l}\text { The ratio of the total number of the stream segments to the area of the } \\
\text { basin. The values of stream frequency indicate the degree of slope } \\
\text { steepness, rock permeability and surface runoff. }\end{array}$ & $\begin{array}{l}\text {-Tectonics/seismicity } \\
\text {-Flooding } \\
\text {-Landslide } \\
\text {-Erosion }\end{array}$ & Horton, 1945 \\
\hline $\begin{array}{l}\text { Slope gradient } \\
(S)\end{array}$ & $\begin{array}{l}\text { Slope }=\sqrt{\left(G^{2}+H^{2}\right)}, \\
\text { where } G \text { is the east-to-west gradient } \\
\text { and } H \text { is the north-to-south gradient }\end{array}$ & $\begin{array}{l}\text { Slope gradient algorithm shows maximum slope steepness, indicating } \\
\text { the change in elevation between each cell and its neighbors, thus } \\
\text { allowing relationships in basin morphometry to be determined. }\end{array}$ & $\begin{array}{l}\text {-Tectonics/seismicity } \\
\text {-Landslide } \\
\text {-Vegetation vs } \\
\text { archaeology }\end{array}$ & Evans, 1979 \\
\hline $\begin{array}{l}\text { Topographic } \\
\text { Wetness Index } \\
(T W I)\end{array}$ & $\begin{array}{l}T W I=\ln (A s / \tan b) \text {, } \\
\text { where } A s \text { is the upslope contributing } \\
\text { area and } \tan b \text { is the local slope. }\end{array}$ & $\begin{array}{l}\text { Determines the spatial distribution of soil moisture and surface } \\
\text { saturation with regard to the influence of topography, based on digital } \\
\text { elevation models (DEMs). Narrow V-shaped valleys can be } \\
\text { determined as a characteristic aspect of active tectonics. }\end{array}$ & $\begin{array}{l}\text {-Tectonics/seismicity } \\
\text {-Landslide } \\
\text {-Erosion } \\
\text {-Vegetation vs } \\
\text { archaeology }\end{array}$ & Beven and Kirkby, 1979 \\
\hline $\begin{array}{l}\text { Lineament } \\
\text { density }(L d)\end{array}$ & & $\begin{array}{l}\text { The total length of lineaments that fall within each cell of generated } \\
\text { grid. }\end{array}$ & -Tectonics/seismicity & $\begin{array}{l}\text { Ananaba and Anjakaiye, } \\
1987\end{array}$ \\
\hline $\begin{array}{l}\text { Lineament } \\
\text { frequency }(L f)\end{array}$ & & $\begin{array}{l}\text { The total number of lineaments that fall within each cell of generated } \\
\text { grid. }\end{array}$ & -Tectonics/seismicity & $\begin{array}{l}\text { Briere and Scanlon, } \\
2000\end{array}$ \\
\hline Lithologies (Lth) & & $\begin{array}{l}\text { The lithologies classification based on GSI regarding the rock type } \\
\text { strenghness. }\end{array}$ & -Tectonics/seismicity & $\begin{array}{l}\text { Marinos and Hoek, } \\
2000\end{array}$ \\
\hline
\end{tabular}

Table 2. Matrix of weights evaluation with pairwise comparisons in analytic hierarchy process.

\begin{tabular}{|c|c|c|c|c|c|c|c|c|c|}
\hline & Ar & SLk & Ld & Lf & Dd & Fu & S & TWI & Lth \\
\hline $\boldsymbol{A r}$ & 1 & 1 & 2 & 2 & 4 & 4 & 2 & 5 & 4 \\
\hline $\boldsymbol{S L k}$ & 1 & 1 & 3 & 3 & 2 & 2 & 3 & 5 & 4 \\
\hline $\boldsymbol{L d}$ & 0.5 & 0.333 & 1 & 1 & 3 & 3 & 3 & 6 & 4 \\
\hline $\boldsymbol{L f}$ & 0.5 & 0.333 & 1 & 1 & 3 & 3 & 3 & 6 & 4 \\
\hline $\boldsymbol{D d}$ & 0.25 & 0.5 & 0.333 & 0.333 & 1 & 1 & 2 & 2 & 3 \\
\hline $\boldsymbol{F u}$ & 0.25 & 0.5 & 0.333 & 0.333 & 1 & 1 & 2 & 2 & 3 \\
\hline $\boldsymbol{S}$ & 0.5 & 0.333 & 0.333 & 0.333 & 0.5 & 0.5 & 1 & 3 & 4 \\
\hline $\boldsymbol{T W I}$ & 0.2 & 0.2 & 0.1667 & 0.1667 & 0.5 & 0.5 & 0.333 & 1 & 4 \\
\hline Lth & 0.25 & 0.25 & 0.25 & 0.25 & 0.333 & 0.333 & 0.25 & 0.25 & 1 \\
\hline
\end{tabular}


Table 3. Calculations extracted by analytic hierarchy process for criteria weights and consistency ratio. An acceptable consistency exists among the factors as the value of $C R=$ 0.067 , not exceeding value of 0.1 .

\begin{tabular}{|c|c|c|c|}
\hline Eigenvalues & $\begin{array}{c}\text { Eigenvector of } \\
\text { largest Eigenvalue }\end{array}$ & $\begin{array}{l}\text { Criteria } \\
\text { weights }\end{array}$ & Consistency ratio $(C R)$ \\
\hline 9.776 & 0.53 & $0.22(S L k)$ & \multirow{9}{*}{$\begin{array}{c}\text { (revision of preference } \\
\quad \text { values if } C R>0.1 \text { ) }\end{array}$} \\
\hline 0.0428 & 0.55 & $0.21(A r)$ & \\
\hline 0.0428 & 0.38 & $0.15(L d)$ & \\
\hline-0.1619 & 0.38 & $0.15(L f)$ & \\
\hline-0.1619 & 0.18 & $0.7(D d)$ & \\
\hline-0.2688 & 0.18 & $0.7(F u)$ & \\
\hline-0.2688 & 0.17 & $0.06(S)$ & \\
\hline 0 & 0.10 & $0.04(T W I)$ & \\
\hline 0 & 0.07 & $0.03($ Lth $)$ & \\
\hline
\end{tabular}



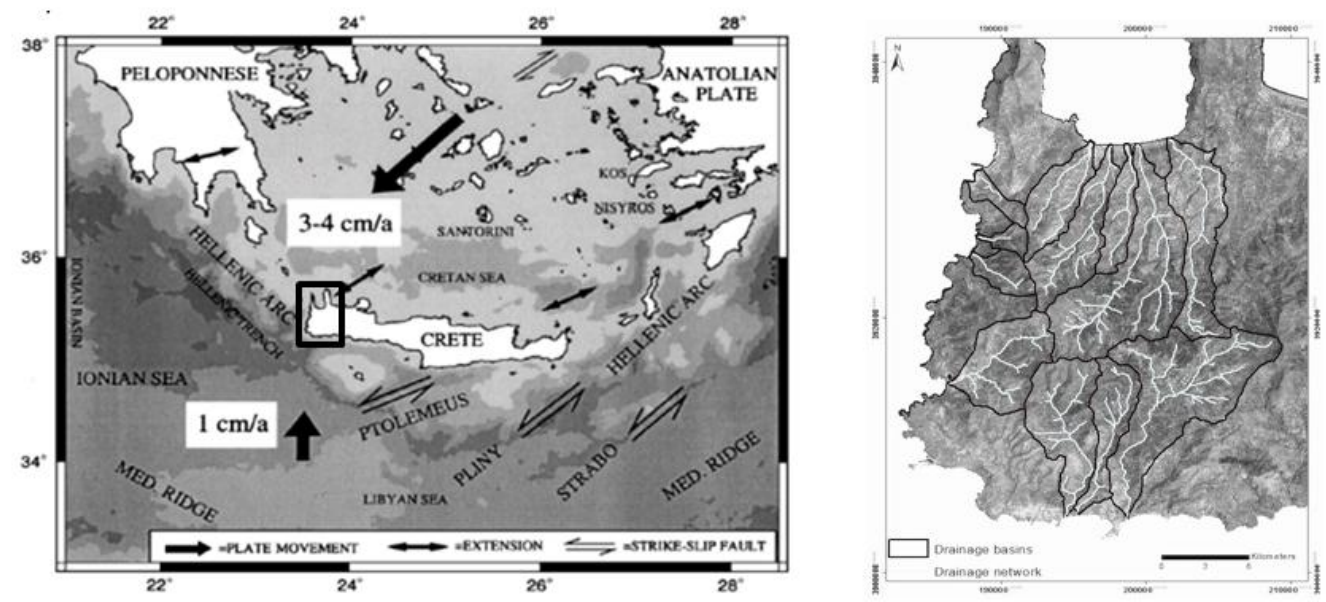

Fig. 1. Location of the Aegean region with the major tectonic regime characteristics (modified from Bohnhoff et al., 2001) and the study area (square box) with the examined drainage basins and drainage network on the right image.

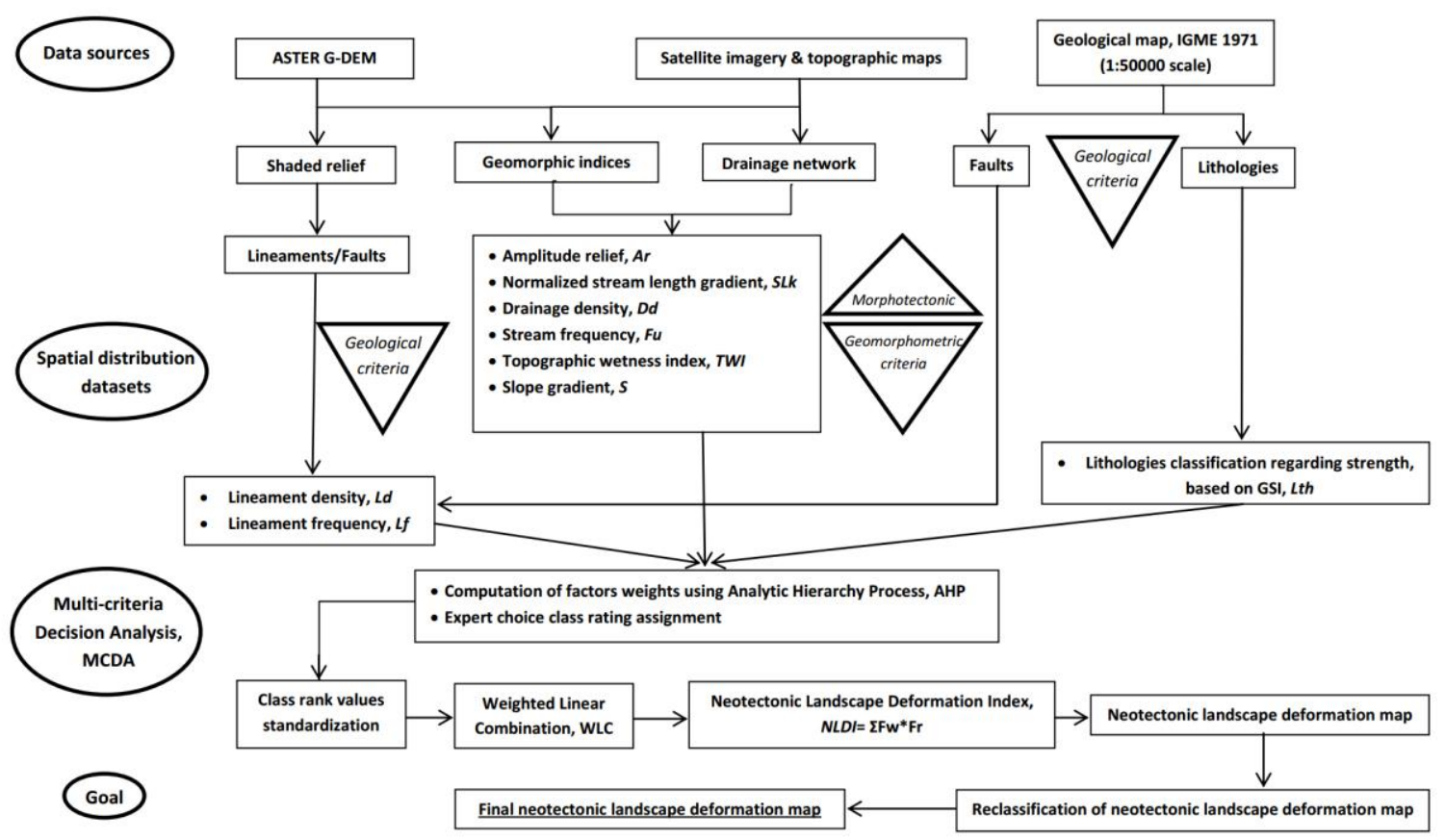

Fig. 2. Flow chart showing the data sets and methodological framework for the neotectonic landscape deformation analysis. 


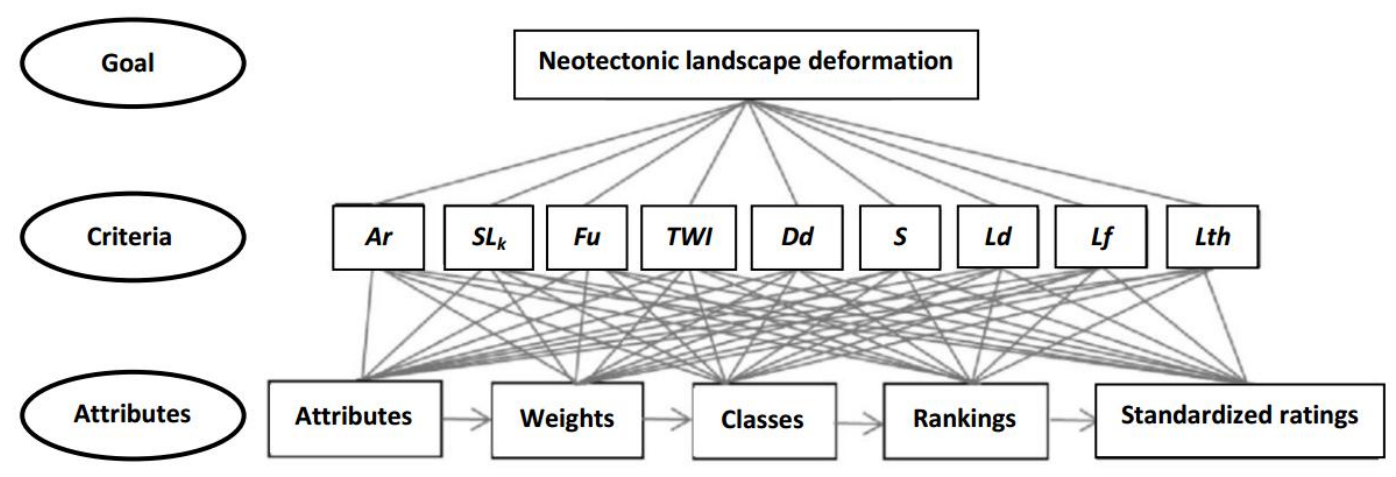

Fig. 3. Pair-wise comparison between the factors, with the individual analytic hierarchy and weighted linear combination sub-procedures. 

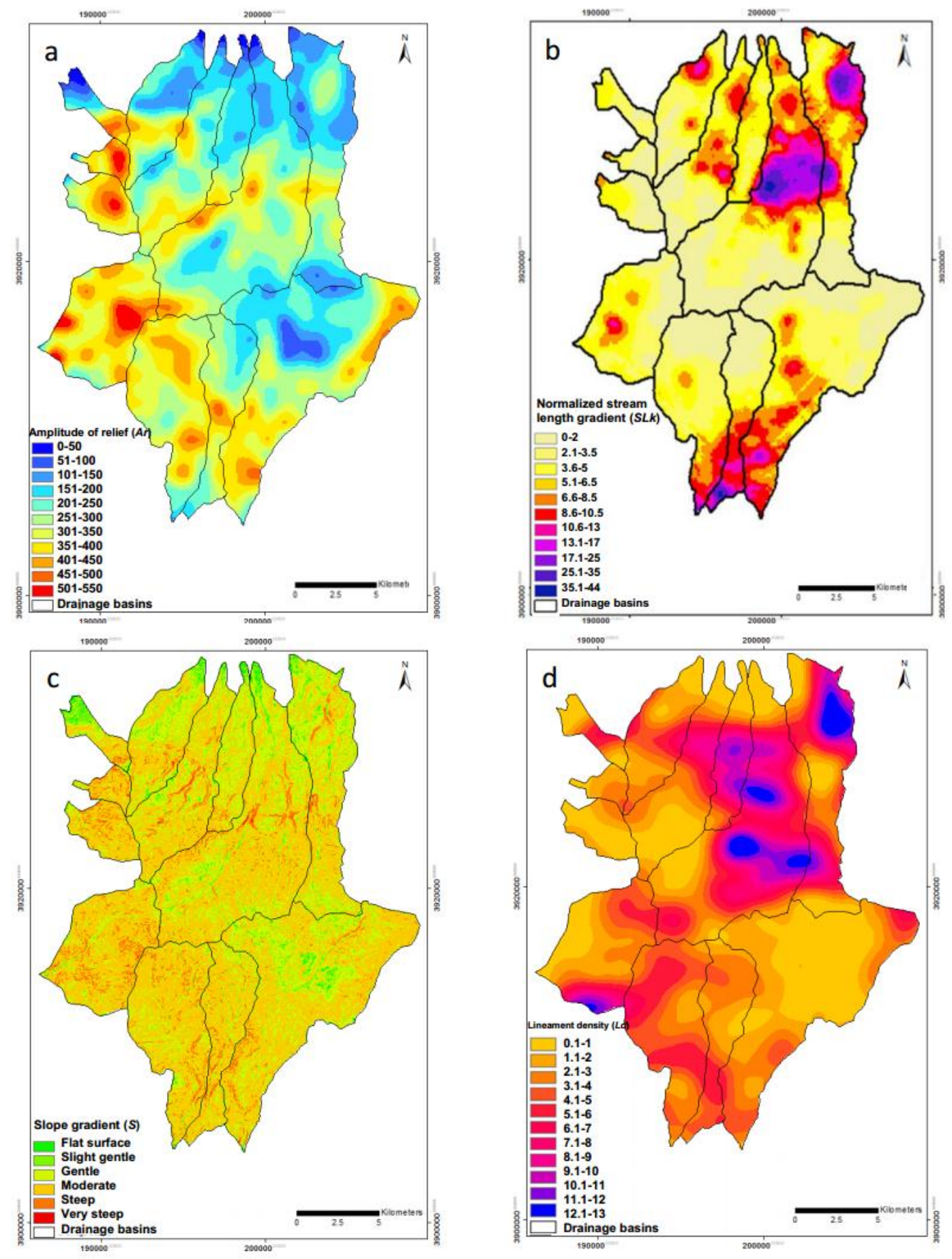

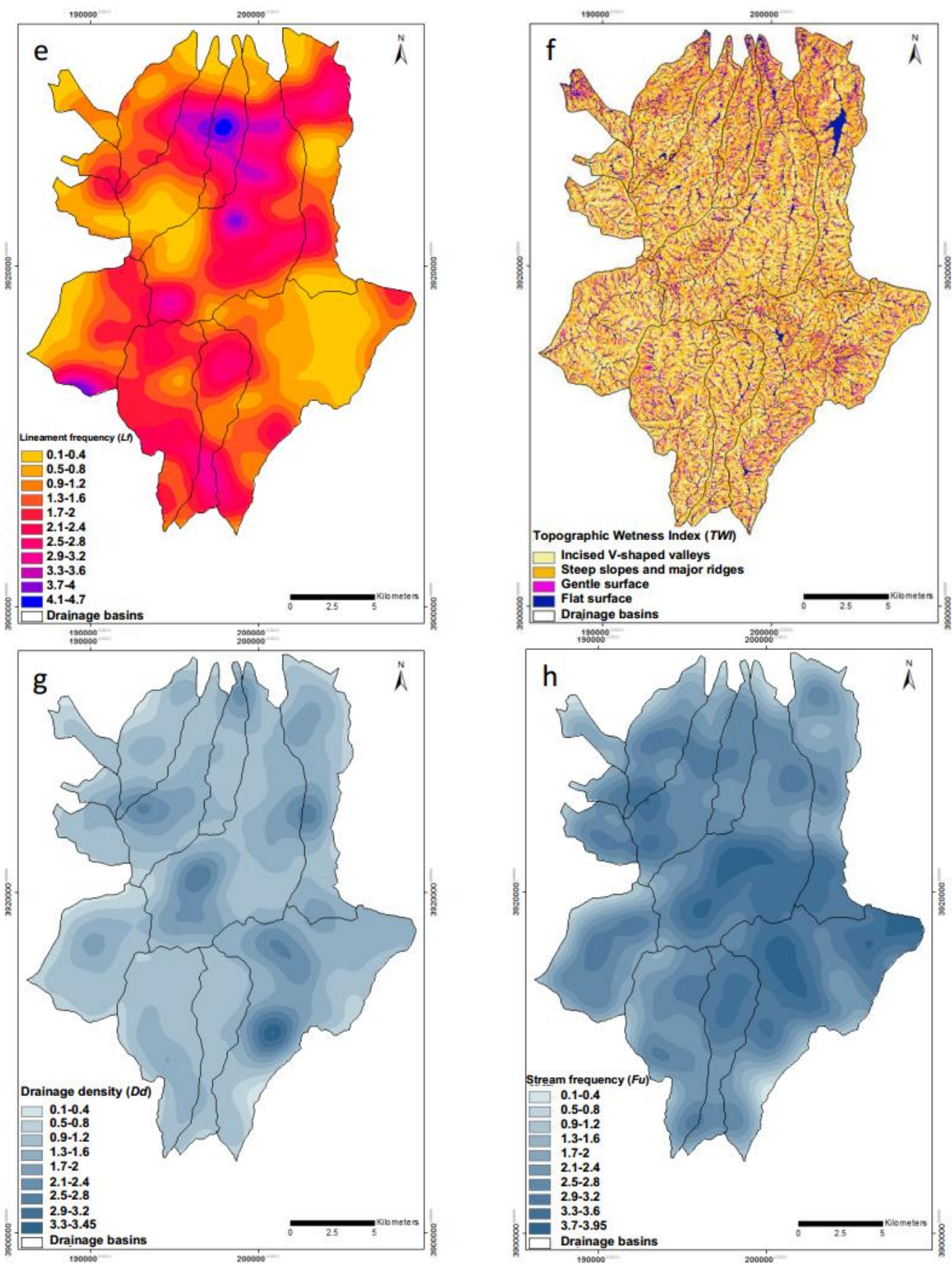


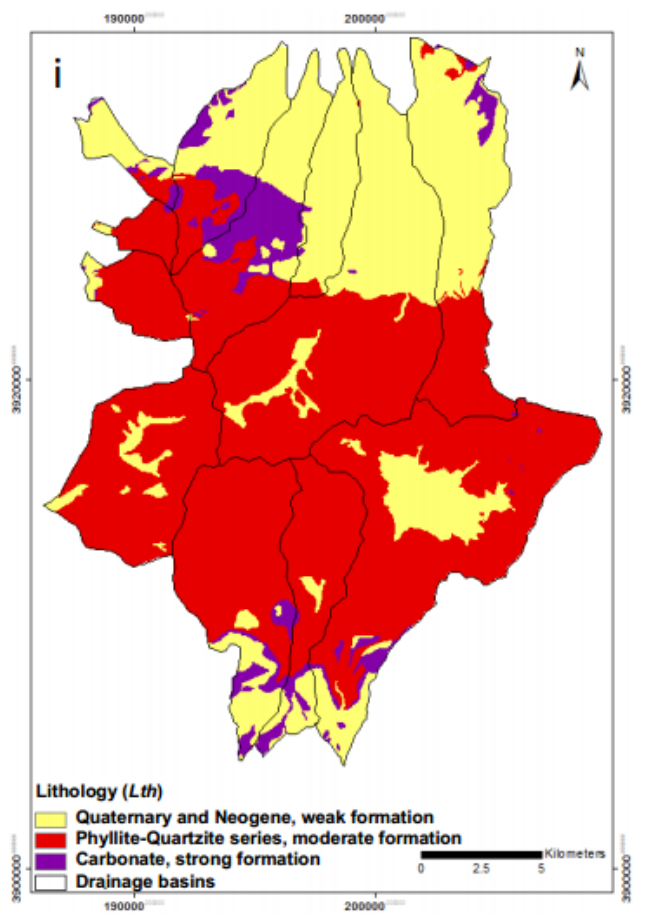

Fig. 4. Thematic map layers to be used in the GIS MCDA approach for the western Crete drainage basins: a) $A r$; b) $S L k$; c) $S$; d) $L d$; e) $L f$; f) $T W I$; g) $D d$; h) $F u$ and; i) $L t h$. 


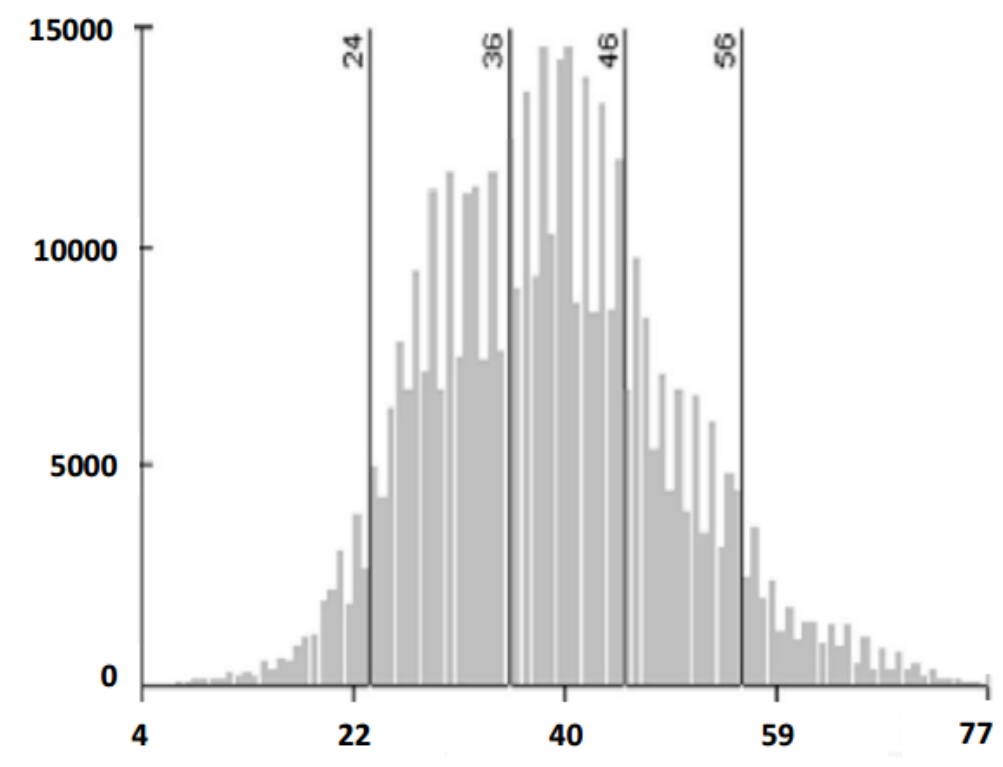

Fig. 5. Natural breaks in the frequency distribution histogram of the values are considered for the grouping. 


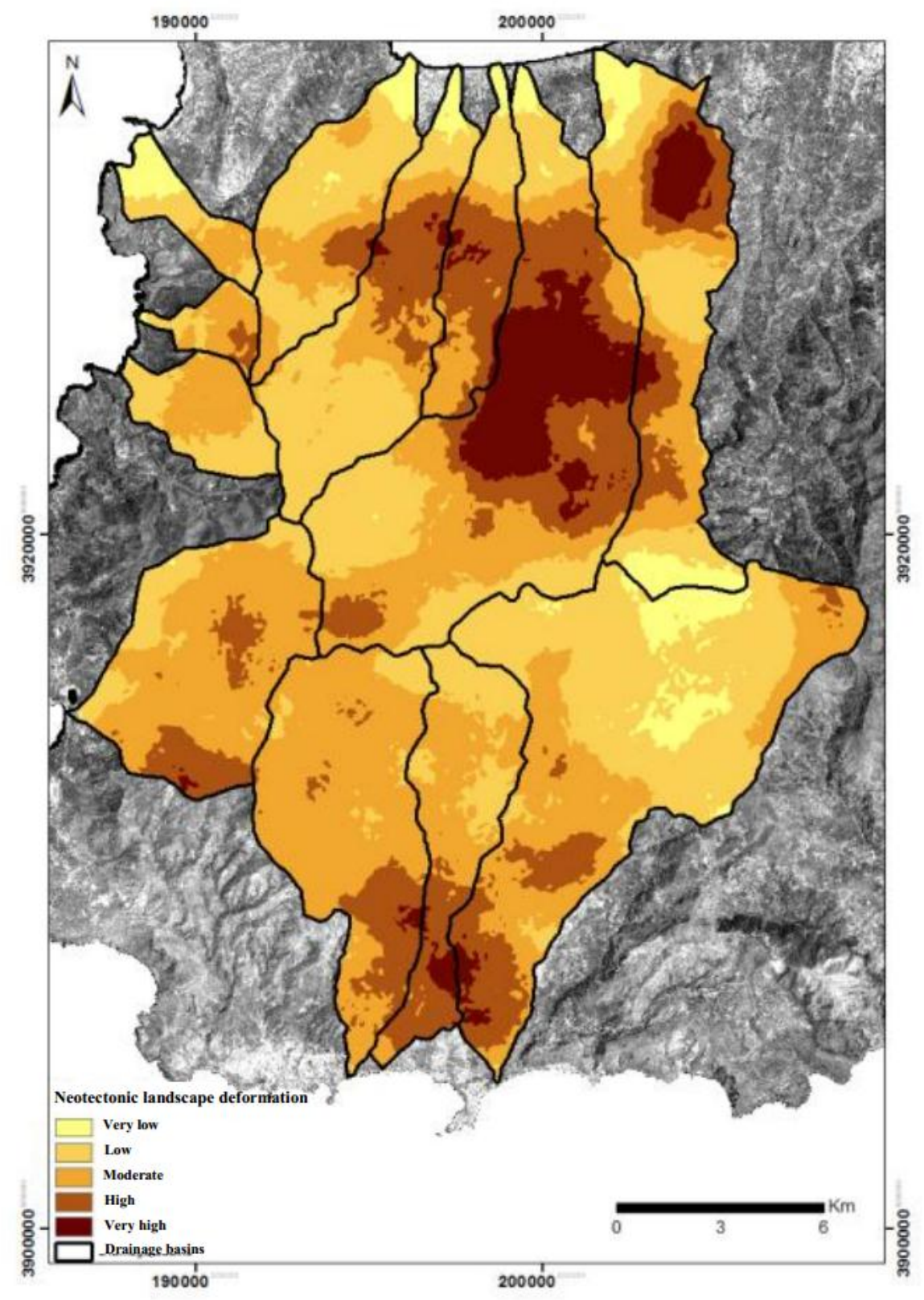

Fig. 6. Neotectonic landscape deformation map of western Crete, overlain on a Landsat ETM+ TM8 panchromatic band. The darker zones indicate the highest degree of neotectonic landscape deformation. 


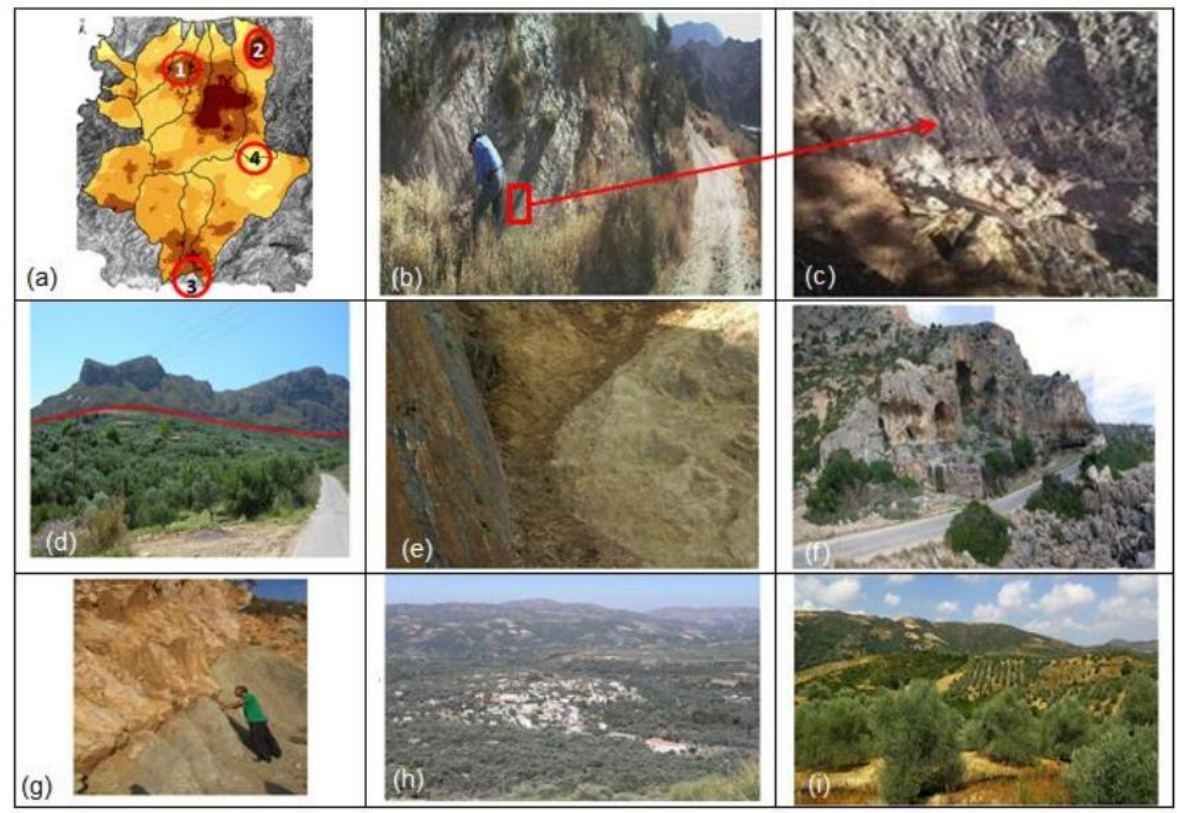

Fig. 7. Map set illustrating the fieldwork visits for the validation of the neotectonic landscape deformation. (a) Neotectonic landscape deformation map with locations of ground truthing surveys (1 to 4); (b) Location 1: Ground truthing of E-W striking fault plane that offsets young deposits; fault breccia and slickenlines are exposed: Fault plane with an NE-SW strike of $80^{\circ}$ and a dip of $67^{0}$ to north. Oblique slip is recorded by slickenlines; (c) Location 1: Slickenlines identified within the fault plane with a strike of $80^{\circ}$; (d) Location 2: Keras active fault overview; (e) Location 2: Keras active fault plane; (f) Location 3: fault bounded sequence of marine notches and caves, beginning at $\sim 9 \mathrm{~m}$; (g) Location 3: en echelon ENE-WSW fault set, both normal and reverse slip; massive white limestone in hanging wall, while footwall in sheared shaley limestone and, further east, buff marls; (h-i) Location 4: areas of "low" neotectonic landscape deformation (e.g. Kandanos), characterized by alluvial deposits and not a rough terrain. 